Revista do Programa de Pós-Graduação em Artes da Cena, Universidade Estadual de Campinas

\title{
Artes da Cena e Direitos Humanos (Editorial)
}

\section{Performing Arts and Human Rights (Editorial)}

Ana Maria Rodriguez Costas ${ }^{1}$

A Conceição|Conception dedica o presente número a artigos inéditos comprometidos com a temática Artes da Cena e Direitos Humanos. Em um cenário nacional e internacional marcado por crescentes violações aos direitos humanos, pareceu fundamental levar a conhecer as várias maneiras em que as Artes da Cena vêm se fazendo presente na resistência contra a censura, contra a repressão política e ideológica e como campo para construir ações, projetos, programas, micro e macropolíticas em resposta à discriminação, à intolerância e à violência de qualquer natureza: gênero, raça, etnia, deficiência, ideologia, religião, econômica, social, etc.

As publicações aqui reunidas apontam para as diversas vertentes em que os Direitos Humanos têm sido objeto de estudo, reflexão e ações, de modo a evidenciar as contribuições das artes da cena contemporânea - dança, teatro, performance - na afirmação da democracia, da cultura de paz, do respeito à diversidade e para o encontro (invenção) de novas formas de convívio e sociabilidade.

No primeiro artigo, Marta Haas enfoca a prática artística do Grupo Cultural Yuyachkani (Peru) e da Tribo de Atuadores Ói Nóis Aqui Traveiz (Brasil). Refletindo sobre as relações entre teatro e o direito à memória, a autora chama atenção para o compromisso ético e político desses coletivos com a resistência e a defesa dos direitos humanos na América Latina.

Na sequência, partindo de uma abordagem crítica ao pensamento colonizador, Helder Carlos de Miranda, Patricia Ordaz Gusmán, Elderson Melo e Renata de Lima Silva procuram

\footnotetext{
${ }^{1}$ Professora do Curso de Graduação em Dança e do PPG Artes da Cena do Instituto de Artes da UNICAMP. Mestre em Artes e Doutora em Educação pela UNICAMP. Pós-doutorado no PPGAC da ECA/USP. ORCID: https://orcid.org/0000-0002-4088-4838. Contato: anaterra@unicamp.br
} 
Revista do Programa de Pós-Graduação em Artes da Cena, Universidade Estadual de Campinas

Performing Arts Graduate Program Journal, University of Campinas

refletir sobre as potencialidades vocais provindas de performances afro-ameríndias no encontro entre duas pesquisas realizadas em contextos culturais distintos - uma no México e outra no Brasil -, em uma disciplina desenvolvida no Programa de Pós-Graduação Interdisciplinar em Performances Culturais na Universidade Federal de Goiás. Com o intuito de desenvolver proposições sobre "poetnografias vocais" e seus possíveis encaminhamentos metodológicos, as autoras e autores apontam para o potencial da poetnografia em valorizar e recolocar outros saberes nos campos artísticos.

O artigo de Melissa da Silva Ferreira reflete sobre os direitos da criança no campo da experimentação artística. Partindo da análise de algumas obras cênicas que confrontam-se com concepções conservadoras de infância, o trabalho focaliza as dimensões estéticas, éticas e políticas implicadas na participação de crianças na cena contemporânea.

$\mathrm{Na}$ forma de um relato de experiência, Mariana Baruco Machado Andraus e Erika Carolina Cunha Rizza de Oliveira discorrem sobre a disciplina Dança e Direitos Humanos, oferecida junto ao curso de Bacharelado em Dança e ao Programa de Pós-Graduação em Artes da Cena da Universidade Estadual de Campinas (Unicamp) durante o primeiro semestre de 2019. Além de apresentar alguns dos programas performativos desenvolvidos por alunos e alunas junto à comunidade do campus, as docentes, também autoras, refletem sobre o potencial das ações artísticas na gestação de relações sociais mais acolhedoras ao divergente, ao contraditório e, simultaneamente, mais propícias a outros devires.

Por fim, o ensaio de Katharina Souza Câmara percorre experiências corporais, artísticas e investigativas em dança, entrelaçando-as com reflexões sobre os conceitos de lugar, corpografia e performance nas ruas, em uma teia que ilumina o vigor da arte em promover encontros. 